\title{
Prawna ochrona nazw domen internetowych
}

$\mathbf{R}_{\text {w ciagu zaledwie ostatnich kilku lat, ma bezprecedensowy wymiar. }}^{\text {ewolucja w komunikacii, która dokonała sie dziêki Sieci internetowej }}$ Niemal codziennie słyszymy o nowych zastosowaniach tego środka przekazu, który wkracza w nasze życie znacznie intensywniej niż inne, dotychczas znane środki. Interaktywność, szybkość działania, nadterytorialność, brak ograniczeń w swobodzie wypowiadania się oraz ogromna wartość informacyjna - to cechy, którym „ogólnoświatowa pajęczyna” zawdzięcza swoją popularność.

Burzliwy rozwój tego nowego środka społecznego przekazu, jakim jest Internet, doprowadził do sytuacji, w której zasady funkcjonowania ogólnoświatowej Sieci - początkowo oparte na całkowitej dowolności i specyficznych „dobrych obyczajach”, musiały zostać w jakiś sposób uporządkowane. Konieczność ta zrodziła się z faktu postępującej komercjalizacji Internetu, traktowanego coraz częściej nie tylko jako technologiczna nowinka, ale już jako normalne narzędzie pracy - narzędzie, bez którego niemożliwe wydaje się dziś działanie żadnego poważnego przedsiębiorstwa. Coraz szersze wykorzystanie nowej technologii w biznesie powoduje, że tworzenie dobrych rozwiązań prawnych, chroniących zarówno przedsiębiorców, jak i osoby prywatne, warunkuje obecnie także dalszy rozwój Internetu.

Ciagle pojawiające się, nowe rodzaje naruszeń przepisów i zasad niosą ze sobą również nowe wyzwania dla prawa. Pomimo tego, że Polska jest państwem o stosunkowo niewielkim „stażu internetowym”, omawiany rozwój dał się zauważyć również w naszym kraju. Podobnie jak wszędzie na świecie, tak i w Polsce niezbędne stało się wypracowanie odpowiednich regulacji, pozwalających na ochronę coraz chętniej korzystających z nowego narzędzia przedsiębiorców oraz rzeszy zwykłych internautów. Szczególnie duże możliwości dla popełniających nadużycia stwarza konstrukcja systemu rejestracji nazw domen internetowych, pozwalającego niejednokrotnie na bezprawne wykorzystywanie cudzych dóbr, w celu od- 
niesienia bezpośrednich korzyści lub jako elementu nieuczciwej walki konkurencyjnej.

Aby przybliżyć pojęcia domeny internetowej, należy wyjaśnić podstawowe zasady, regulujące przesyłanie danych w Sieci. Każdy komputer, podłączony do Internetu (ang. host), posiada własny numer (tzw. numer IP) ${ }^{1}$, składający się z ciagu cyfr oddzielonych kropkami, unikalnego dla każdej maszyny. Jest to element niezbędny do identyfikacji komputera i umożliwia on oprogramowaniu przesyłanie danych w sieci. Przykładowy adres IP może wyglądać następująco: 195.116.90.47. Ponieważ adresy komputerów zapisywane w tym układzie są trudne do zapamiętania i z niczym się nie kojarzą użytkownikom, zadecydowano o wprowadzeniu systemu nazw adresów domenowych (ang. Internet Domain Names), będących „tłumaczeniem” numerów IP na postać słowną. System ten działa w dwie strony, gdyż zapewnia również zamianę adresów wprowadzonych jako słowa na numery IP. Dzięki temu identyfikacja poszczególnych komputerów w sieci jest znacznie prostsza. Pomysł wprowadzenia czytelniejszego systemu adresów internetowych został przedstawiony we wrześniu 1981 roku przez D. L. Millsa. Idea domen internetowych narodziła się i doczekała realizacji na początku lat osiemdziesiątych na uniwersytecie w Wisconsin. Wdrożeniem systemu zajęła się amerykańska organizacja Internet Assigned Numbers Authority (IANA), która realizowała to zadanie na mocy kontraktu, zawartego z rządem USA ${ }^{2}$.

Pojęcie domeny internetowej może być rozumiane na kilka sposobów: - jako znaczenie techniczne - system tłumaczenia nazw na adresy IP, - jako znaczenie użytkowe, czyli identyfikator pozwalający użytkownikowi na odnalezienie w Internecie konkretnej informacji (np. w postaci skrótu typu: edu, pl, net czy com),

- jako istnienie elementu cyberprzestrzeni, w którym znajdują się zapisane adresy stron internetowych, należących do określonej domeny,

- jako znaczenie prawno-ekonomiczne, w którym domena jest znakiem o określonej wartości majątkowej, wynikającej z jego funkcji identyfikacyjnej oraz stanu wyłączności, powstałego w wyniku umowy pomiędzy

${ }^{1} \mathrm{Z}$ ang. Internet Protocol (protokół internetowy, a raczej numer identyfikacyjny komputera - adres IP nie jest w rzeczywistości adresem hosta - jest przyporządkowany do interfejsu sieciowego tegoż hosta. Zob.: C. Hunt, TCP/IP. Administracja sieci, s. 30 .

2 M. Kondrat, Znaki towarowe w Internecie, Warszawa 2001, s. 31. 
abonentem a rejestratorem bądź w drodze czynności administracyjno-prawnej ${ }^{3}$.

Warto również zauważyć, że w posługiwaniu się słowem „domena” częstokroć brak precyzji pojęciowej, gdyż „domeną” nazywa się często zarówno cały adres internetowy (www.adres.com.pl), jak jego część z pominięciem prefiksu ,www”, a nawet sam sufiks ,..pl”.

Niebagatelne znaczenie ma tutaj również fakt, iż procent transakcji handlowych, zawieranych za pośrednictwem globalnej Sieci, stale wzrasta. Efektem tej sytuacji jest zmiana, a właściwie poszerzenie funkcji adresów domenowych. Do ich pierwotnego znaczenia - czyli identyfikacji konkretnego komputera, doszło obecnie znaczenie handlowe - w tym również reklamowe, a nawet gwarancyjne. Można to uznać za przyjęcie przez nazwy domenowe funkcji znaków odróżniających przedsiębiorstwo - zwłaszcza znaków towarowych.

Istnieje kilka rodzajów adresów internetowych, pełniących różne funkcje $\mathrm{e}^{4}$ :

1. Adresy stron WWW, zapisywane w postaci URL (ang. Uniform Resource Locator): HTTP://WWW.DOMENA3.DOMENA2.DOMENA1/ŚCIEŻKA DOSTĘPU DO DOKUMENTU. Należy tutaj dodać, że do identyfikowania adresów stron głównych poszczególnych serwisów internetowych wystarcza podanie samego adresu domenowego (nie jest konieczne wprowadzanie ani nazwy protokołu, ani pełnej ścieżki dostępu do dokumentu głównego).

2. Adresy skrzynek poczty elektronicznej (e-mail), zapisywane w postaci dwóch części, przedzielonych znakiem „@” [at] - tzw. polska „małpa”. Pierwsza z nich to identyfikator użytkownika (tzw. login name lub userid), druga natomiast to adres domenowy, do którego należy dana skrzynka - użytkownik@domena2.domena 1. - np. biuro@wp.pl.

Domeny dzielą się na dwie grupy:

- generyczne (podstawowe), wskazujące dziedzinę działalności czy też branżową przynależność instytucji posiadającej dany komputer:

- .com: o przeznaczeniu komercyjnym,

- .edu: dla instytucji edukacyjnych,

3 Takie rozumienie pojęcia domeny podaję za: http://www.nask.pl/news/seminarium/apiechocki.pdf, s. 3 .

4 R. Chmura, W. Włodarczyk, Bezprawne używanie zarejestrowanych znaków towarowych $w$ adresach domenowych $w$ świetle ustawy o znakach towarowych, w: Internet - problemy prawne, pod red. R. Skubisza, Lublin 1999, s. 85 i n. 
- .gov: wyłącznie dla instytucji i agencji federalnego rządu Stanów Zjednoczonych Ameryki Północnej,

- ./a/t: dla organizacji działających na mocy międzynarodowych układów,

- .mil: dla armii USA,

- .net: z przeznaczeniem dla instytucji, zajmujących się funkcjonowaniem Internetu oraz dostawców usług internetowych (ISP),

- .org: dla pozostałych organizacji, nie mieszczących się w powyższych kategoriach, zwłaszcza dla pozarządowych organizacji non-profit;

- krajowe - składające się z dwuliterowego kodu kraju, zawartego w normie ISO $3166^{5}$. Informują one bezpośrednio o kraju pochodzenia podmiotu. W obecnej chwili jedynie Stany Zjednoczone nie posiadają własnej domeny krajowej, ze względu na to, iż kraj ten jest niejako „ojczyzną" Internetu.

International Ad Hoc Committee wysunął postulat utworzenia siedmiu nowych domen pierwszego poziomu: .firm - dla firm prywatnych i innych instytucji komercyjnych, jako alternatywa dla istniejącej obecnie domeny .com, store - dla sklepów internetowych i sprzedaży towarów, .web - dla instytucji, których działalność związana jest z WWW, .arts - dla kultury i sztuki, .rec - dla rekreacji i rozrywki, .info - dla serwisów informacyjnych, .nom - dla osób prywatnych.

Podczas spotkania roboczego, które odbyło się 16 listopada 2000 roku, ICANN $^{6}$ podjęła decyzję o rozpoczęciu negocjacji w sprawie porozumień, umożliwiających włączenie do systemu nazw domenowych następujących siedmiu domen: .aero (dla cywilnego przemysłu lotniczego i podmiotów związanych z komunikacją lotniczą), .e/z (dla zastosowań biznesowych, w szczególności w celu zmniejszenia liczby rejestracji w domenie .com), .coop (dla wspólnot i spółdzielni), .info (w której rejestracje powinny mieć charakter otwarty), .museum (dla muzeów), .name (z przeznaczeniem dla osób zainteresowanych posiadaniem własnych stron internetowych) oraz .pro (dla przedstawicieli wolnych zawodów). Warto zauważyć, iż jest to pierwsze wzbogacenie listy domen najwyższego poziomu od roku 1988 (nie licząc dodawania domen krajowych). Zanim jed-

5 Listę kodów krajowych ISO 3166 można znaleźć pod adresem: $\mathrm{ftp}: / / \mathrm{ftp}$.nask.pl/pub/hostcount/iso3166-countrycodes.

${ }^{6}$ ICANN, Internet Corporation for Assigned Names and Numbers, http://www.icann.org. 
nak nowe domeny staną się aktywne (tj. możliwe będzie rejestrowanie i aktywnienie), ich operatorzy lub sponsorzy muszą zawrzeć odpowiednie umowy z ICANN. W maju 2002 roku umowy te zostały zawarte dla wszystkich domen.

Obecnie istnieją trzy rodzaje domen drugiego poziomu:

- ogólnokrajowe - zarejestrowane bezpośrednio w domenie krajowej (np.: nazwa.pl, nazwa.fm),

- funkcjonalne - opisujące funkcję, pełnioną przez domenę w odniesieniu do działalności jej właściciela (np.: nazwa.edu.pl),

- regionalne - wskazujące na związek właściciela domeny z określonym regionem, miastem, etc. (np.: NAZWA.POZNAN.PL, NAZWA.WROCLAW.PL).

Brzmienie nazwy jest ustalane przez podmiot, zamierzający wprowadzić do Sieci WWW swoją stronę. Najczęściej nazwą domeny jest nazwa przedsiębiorstwa, imię bądź nazwisko lub też jakiekolwiek inne oznaczenie odróżniające - głównie w postaci znaku towarowego itp. Zatem niezbędne jest czytelne odróżnienie nazwy domeny od pojęcia domeny, bowiem to właśnie nazwa domeny, a nie sama domena podlega rejestracji oraz powinna być przedmiotem ochrony prawnej ${ }^{7}$.

Budowa nazwy domeny jest w pewnym sensie analogiczna do budowy innego dobra niematerialnego, jakim jest firma. Podobnie jak w przypadku wymienionego oznaczenia indywidualizującego, w nazwie domenowej można wyodrębnić dwa elementy charakterystyczne: corpus i dodatki. Corpus stanowią oznaczenia, które indywidualizują w sposób bezpośredni podmiot, będący posiadaczem danego adresu. W nazwie domenowej mogą występować słowa, litery, cyfry, firmy, nazwy przedsiębiorców bądź znaki towarowe ${ }^{8}$. Należy jednak zauważyć, że Internet w pewien sposób ogranicza wykorzystywanie wymienionych oznaczeń. Bez znaczenia jest bowiem ich forma graficzna, gdyż adresy internetowe są podawane przy pomocy standardowych czcionek, a tym samym nie uwzględniają dodatkowych oznaczeń (takich jak elementy graficzne, stylizacja, krój liter itp.).

7 Wyłączając przypadki, gdy dochodzi do sporów pomiędzy dostawcami usług internetowych, dotyczących uprawnień do administrowania domenami internetowymi.

8 Występowanie niektórych znaków jest czasami ograniczane - bądź ze względów technicznych, bądź z powodu specyficznych wymogów operatora danej domeny. 
Niezależnie od tego, że nie istnieją w tej kwestii żadne wyraźne wskazania, należałoby przyjać, że nazwa domeny nie może być określana w zupełnie dowolny sposób. Adres internetowy (w znaczeniu adresu strony WWW) nie powinien przede wszystkim wprowadzać w błąd użytkowników Sieci co do potencjalnej zawartości stron, które mają oni zamiar odwiedzić. Niestety, zasada ta jest nader często łamana; wystarczy wspomnieć tutaj klasyczny już przykład istnienia serwisu whitehouse.com, pod którym to adresem użytkownik nie znajdzie bynajmniej informacji na temat Białego Domu.

Do dnia dzisiejszego społeczność międzynarodowa nie wypracowała jednolitego zestawu zasad, regulujących kwestie rejestracji domen w Internecie, pomimo raczej powszechnej zgody co do faktu, iż dostęp (i istnienie) w Sieci, jakkolwiek wolny, powinien zostać w jakiś sposób zorganizowany. Ustalenie zasad przyznawania prawa do sprawowania kontroli nad określonym wycinkiem przestrzeni wirtualnej zmusza do wypracowania stanowiska w kilku fundamentalnych kwestiach.

Ponieważ Internet nie posiada scentralizowanych władz, trudne było określenie, kto miałby decydować o przyznawaniu nazw domenowych. Obecnie zajmują się tym w poszczególnych krajach podmioty, które przypisały sobie prawo do administrowania domenami i ich przydzielania. $\mathrm{Na}$ ogół są to dostawcy usług internetowych (ISP). W związku z tym faktem powstaje wiele niezwykle trudnych do rozwiązania problemów, zwłaszcza, że częstokroć nie jest możliwe ustalenie podstawy, na jakiej dany podmiot przypisał sobie prawo do zarządzania domenami. Areną najgłośniejszych sporów na tym tle były Stany Zjednoczone. Nic dziwnego sprawa rozgrywała się o wielkie pieniądze.

W Polsce rejestracją nazw domen internetowych zajmuje się NASK (Naukowa i Akademicka Sieć Komputerowa) ${ }^{9}$, organizacja działająca od 1991 roku $^{10}$, powstała z inicjatywy Komitetu Badań Naukowych. Na podstawie koncesji Ministra Łączności na świadczenie usług telekomunikacyjnych transmisji danych oraz na zakładanie i użytkowanie sieci telekomunikacyjnej użytku publicznego, funkcjonuje ona jako dostawca usług internetowych. We wczesnych latach dziewięćdziesiątych NASK połączyła Polskę z siecią Internet i rozbudowała ogólnopolską sieć komputerową. Długo nie znajdowano jednak odpowiedzi na pytanie o podsta-

9 http://www.nask.pl.

10 Podaję za: http://www.nask.pl/o_nas.html. 
wę prawną uznania się przez NASK za administratora większości domen w domenie krajowej .pl. Wywoływało to zresztą protesty zarówno innych dostawców usług internetowych, jak i samych użytkowników ogólnoświatowej Sieci. Najpoważniejsze zarzuty, kierowane pod adresem NASK, dotyczyły niejasnych zasad rejestrowania nazw domen oraz nadużyć związanych z dominującą pozycją na rynku ${ }^{11}$.

Aby uzasadnić prowadzoną działalność, 24 lipca 2001 roku NASK uzyskał opinię wyrażoną przez Urząd Regulacji Telekomunikacji, w której zawarte jest stwierdzenie, iż „[...] działalność polegająca na rejestracji i utrzymaniu domen internetowych jest, zgodnie z przepisem art. 1 ust. 1 pkt 1 Prawa Telekomunikacyjnego, działalnością telekomunikacyjną"12. Ponadto, Główny Urząd Statystyczny i Urząd Statystyczny w Warszawie wydały opinie, stwierdzające, iż ,[...] usługa polegająca na rejestracji i utrzymaniu domeny internetowej jest - zgodnie z Polską Klasyfikacją Wyrobów i Usług - usługą telekomunikacyjną i należy ją klasyfikować jako usługę elektronicznej wymiany danych i wiadomości (PKWiU 64.20.17)"13. Przyjęta przez NASK interpretacja tych opinii sprowadziła się do konstatacji, że faktury za rejestrację i utrzymanie domen internetowych, wystawiane przez NASK, są zgodne z obowiązującym prawem ${ }^{14}$, w szczególności z $§ 38$ ust. 2 pkt 3 Rozporządzenia Ministra Finansów z dnia 22 grudnia 1999 roku w sprawie wykonania niektórych przepisów ustawy o podatku od towarów i usług oraz o podatku akcyzowym (Dz.U. z 1999 r., Nr 109, poz. 1245, z późniejszymi zmianami).

Procedura rejestracji w NASK jest następująca: pierwszym krokiem, jaki musi podjąć podmiot zamierzający zarejestrować domenę, jest przesłanie przez witrynę internetową NASK prawidłowo wypełnionego i przyjętego wniosku w formie elektronicznej. Nie określono, co ma oznaczać pojęcie „prawidłowe wypełnienie wniosku”, jednakże można przyjąć, iż ma w tym przypadku zastosowanie podpunkt c punktu 4 ,Zasad ogólnych rejestracji i utrzymywania domen internetowych przez NASK" ${ }^{\prime 1}$. W przypadku, gdy spełnione są wszystkie określone warunki, a NASK nie znajdzie podstaw do odmowy rejestracji nazwy domeny, zostaje ona zarejestrowa-

11 Sąd Antymonopolowy w wyroku z dnia 29 września 1999 roku oddalił zarzuty wobec NASK, dotyczące stosowania praktyk monopolistycznych.

12 http://www.dns.pl/news.

13 Ibidem.

14 Ibidem.

15 Źródło: http://www.dns.pl/zasady_p.html. 
na w terminie pięciu dni roboczych od doręczenia NASK wniosku w formie pisemnej ${ }^{16}$.

Z zasad wynika, iż podmiot wnioskujący o rejestrację posiada stosunkowo szerokie możliwości w zakresie wyboru nazwy domeny, na które jednak nałożone są pewne ograniczenia. Przede wszystkim, nazwa domeny musi być unikalna, a także powinna kojarzyć się zarówno z nazwą podmiotu, jak i z rodzajem prowadzonej przez niego działalności. Wprawdzie ten ostatni wymóg nie jest określony formalnie - de facto podmiot jedynie deklaruje prawo do nazwy, po czym ewentualnie sprawdzane jest ono przez rejestratora, żądającego od podmiotu dokumentów potwierdzających owo prawo ${ }^{17}$. Rozwiązanie to miało zapobiec zjawisku rejestracji nazwy domeny w złej wierze, jednakże nie przyniosło spodziewanych rezultatów - w Polsce istnieje bowiem zjawisko handlu domenami. Ponieważ możliwa jest sytuacja, gdy więcej niż jeden podmiot jest w stanie udowodnić swoje prawo do konkretnej nazwy podczas ubiegania się o rejestrację, obowiązuje zasada pierwszeństwa, gdyż system nazw domenowych uniemożliwia istnienie dwóch lub więcej domen o identycznych nazwach. Nie istnieje również ograniczenie co do liczby domen, jaką może zarejestrować jeden podmiot.

Na dwudziestu dziewięciu narodowych rejestratorów w Europie, w dziewięciu krajach rejestracją zajmują się jednostki naukowe bądź uczelnie (Włochy, Litwa, Luksemburg, Łotwa, Macedonia, Malta, Rumunia, Rosja oraz Słowenia). Sześć krajów powołało fundacje, zajmujące się rejestracją nazw domen (Belgia, Szwajcaria, Grecja, Holandia, Portugalia i Szwecja), również w sześciu krajach rejestratorami są instytucje lub przedsiębiorstwa rządowe (Estonia, Hiszpania, Finlandia, Chorwacja, Norwegia, a także Andora). W trzech krajach do rejestrowania domen powołano stowarzyszenia (Austria, Francja i Węgry). W pozostałych czterech krajach rejestratorami są przedsiębiorstwa prywatne (Czechy, Niemcy, Irlandia oraz Wielka Brytania) ${ }^{18}$.

Nie istnieją wspólne zasady, rządzące wyłączeniami w nazwach domen. W większości państw rejestratorzy ustalili, które wyrazy nie mogą być użyte jako nazwy domen. Na ogół są to słowa, uznawane za nieprzyzwoite lub obraźliwe, w niektórych krajach istnieje wręcz oficjalna lista

16 Ibidem.

17 Z praktyki wynika, że żądania dostarczenia dokumentów potwierdzających prawo do nazwy domeny zdarzają się stosunkowo często.

18 Podaję za: http://www.nask.pl/seminar/mkozlowskl.pdf, s. 12. 
nazw „zarezerwowanych” (tak jest np. we Włoszech). Część państw wyłączyła możliwość stosowania nazw jednostek administracyjnych, nazw geograficznych czy nazw określających pewne obszary działalności człowieka, takie jak: „sztuka”, ,architektura”, „przemysł” itp. ${ }^{19}$

Polska na tym tle jawi się jako kraj o stosunkowo liberalnych zasadach - wyłączenia nazw dotyczą stosowania nazw jednostek administracyjnych, które mogą być rejestrowane jako domeny jedynie przez organy rządowe lub samorządowe - do szczebla gminy ${ }^{20}$. Z wyłączeniami w nazwach wiąże się sposób przeciwdziałania zjawisku piractwa domenowego, tzw. cybersquattinu ${ }^{21}$. Jest to proceder, polegający na rejestrowaniu domen, zawierających w nazwach charakterystyczne oznaczenia indywidualizujące przedsiębiorstwa, z zamiarem późniejszej ich odsprzedaży prawowitym właścicielom po znacznie zawyżonej cenie. Nawet krajowy monopolista telekomunikacyjny nie ustrzegł się przed zarejestrowaniem przez osobę prywatną domeny tpsa.com, przy czym zawarte na dostępnej pod tym adresem informacje miały charakter ośmieszający Telekomunikację Polską S.A., gdyż skrót TPSA rozwinięto tam jako „Towarzystwo Powszechnego Ssania Abonentów". Osoba, która zarejestrowała tę domenę, twierdziła, iż jej prawo do zarejestrowania takiej nazwy wynika z członkostwa w Towarzystwie Psa ${ }^{22}$. Działania takie niewątpliwie można uznać za niezgodne z prawem (a przynajmniej z dobrymi obyczajami i netykietą), gdyż zakłócają funkcjonowanie konkurencji. Orzecznictwo daje możność uznania takiego postępowania za „użycie w obrocie gospodarczym",23.

Narastający charakter zjawiska spowodował zajęcie w tej sprawie stanowiska przez WIPO i ICANN, a także uchwalenie w Stanach Zjednoczonych Anticybersquatting Consumer Protection Act - prawa, umożliwiającego ochronę przed bezprawną rejestracją i używaniem chronionych

19 Ibidem, s. 15.

20 Zasady rejestracji i utrzymywania domen internetowych przez NASK, obowiązujące od 18 grudnia 2000, pkt 4, podpunkt d, http://www.dns.pl/zasadyJ3.html.

21 Inna nazwa tego zjawiska, spotykana w literaturze, to ,grabież adresów internetowych" (ang. domain name grabbing). Por.: R. Chmura, Piractwo domenowe (cybersquatting) - wybrane zagadnienia, w: Internet. Fenomen społeczeństwa informacyjnego, pod red. ks. prof. T. Zasępy, Częstochowa 2001, s. 251 i n.

22 M. Remisiewicz, WWW bazar, „Wprost” 1999, nr 39, s. 14.

23 J. Ożegalska, Prawne problemy postugiwania się adresami (domenami) internetowymi w obrocie gospodarczym, „Radca prawny” 2001, nr 1, s. 26. 
oznaczeń w nazwach domen ${ }^{24}$. Akt ten przewiduje wysokie grzywny za cybersquatting - do 100000 dolarów i jest jedynym istniejącym obecnie prawem, w którym zawarto definicję grabieży nazw domen internetowych $^{25}$.

Jak wspomniałem wcześniej, jako nazwy domen mogą występować różnorodne oznaczenia. Są to zarówno nazwiska, znaki towarowe, nazwy własne, jak również firmy i nazwy przedsiębiorstw. Powoduje to konieczność stosowania (zależnie od rodzaju oznaczenia) różnych grup przepisów prawa, chroniących poszczególne rodzaje dóbr niematerialnych. Determinantem doboru grupy przepisów będzie więc tutaj typ dobra niematerialnego, użytego w nazwie domeny. Siłą rzeczy różne dla poszczególnych typów dóbr będą zakresy ochrony nazwy domeny, jak również ryzyko, przed którym konieczna będzie ich prawna ochrona.

Za firmę uznaje się, zgodnie z art. 26 Kodeksu handlowego, nazwę, pod którą kupiec rejestrowy prowadzi przedsiębiorstwo ${ }^{26}$. Z tej definicji wynika jasno, iż oznaczenie „firma” ma zastosowanie wyłącznie do spółek prawa handlowego, czyli, według art. 1 § 2 Kodeksu spółek handlowych $^{27}$, do spółek: jawnych, akcyjnych, z ograniczoną odpowiedzialnościa, a także komandytowych. Wydaje się być oczywistym, iż umieszczenie firmy w nazwie domeny internetowej jest jednym z elementów realizowania prawa podmiotu do firmy. Dzięki takiej interpretacji, możliwe byłoby stosowanie prawa firmowego w wyjaśnianiu konfliktów, wynikających ze stosowania firm w nazwach domen.

Oprócz firm, działalność gospodarczą mogą prowadzić również inne podmioty, których funkcjonowanie nie jest regulowane kodeksem handlo-

24 Prawo to weszło w życie 29 listopada 1999 r. Jego treść można znaleźć w Internecie m.in. pod adresem http://www.inta.org/cyberpiracy.htm.

25 A. Szkaradziński, A. Wacławik, Środki ochrony prawnej w przypadkach abuzywnej rejestracji nazw domen internetowych. Uwagi na tle porównawczym, „Transformacje prawa prywatnego" 2000, nr 4, s. 80.

26 Rozporządzenie Prezydenta Rzeczypospolitej z dnia 27 czerwca 1934 r. Kodeks handlowy (Dz. U. z 1934 r., Nr 57, poz. 502; zm.: Dz. U. z 1946 r., Nr 57, poz. 321; z 1950 r., Nr 34, poz. 312; z 1964 r., Nr 16, poz. 94; z 1988 r., Nr 41, poz. 326; z 1990 r., Nr 17, poz. 98; z 1990 r., Nr 51, poz. 298; z 1991 r., Nr 35 poz. 115; z 1991 r., Nr 94, poz. 418; z 1991 r., Nr 111, poz. 480; z 1994 r., Nr 121, poz. 591; z 1995 r., Nr 96, poz. 478; z 1996 r., Nr 6, poz. 43; z 1997 r., Nr 88, poz. 554; z 1997 r., Nr 118, poz. 754; z 1997 r., Nr 121, poz. 769; z 1997 r., Nr 121, poz. 770; z 1999 r., Nr 101, poz. 1178; z 2000 r., Nr 60, poz. 702; z 2000 r., Nr 94, poz. 1037).

27 Ustawa z dnia 15 września 2000 r. kodeks spółek handlowych (Dz. U. z 2000 r., Nr 94, poz. 1037; zm.: Dz. U. z 2001 r., Nr 102, poz. 1117). 
wym bądź kodeksem spółek handlowych. Występują one w obrocie gospodarczym jedynie pod nazwą, a nie firmą ${ }^{28}$. Istnieje wyraźna różnica między tymi dwoma grupami podmiotów. Tylko i wyłącznie do spółek prawa handlowego odnoszą się przepisy prawa firmowego. Pozostałe podmioty, którym ustawodawca umożliwił prowadzenie działalności gospodarczej (tj. spółki cywilne, przedsiębiorstwa państwowe, stowarzyszenia, fundacje czy spółdzielnie), nie są objęte przepisami tegoż prawa. Istniejąca sytuacja powoduje wiele niejednoznaczności - również w kwestii rozwiązywania konfliktów o nazwy domen internetowych poszczególnych podmiotów.

Jak zostało wspomniane wcześniej, firma może być uznana za dobro osobiste podmiotu, który identyfikuje. Oprócz tego posiada ona wartość handlową. Umieszczanie w adresie internetowym nazwy przedsiębiorstwa powoduje powstanie sytuacji, w której adres ten nie będzie pełnił jedynie funkcji określającej położenie w cyberprzestrzeni danego hosta. Nazwa przedsiębiorstwa przydaje mu bowiem dodatkowego znaczenia będzie on odtąd wskazywał na podmiot, który jest identyfikowany przez tę nazwę. Dowodzi to faktu nabycia przez adres internetowy cech oznaczenia indywidualizującego. Takie zaś oznaczenie może być wykorzystywane przez przedsiębiorcę w celach marketingowych.

Znaki towarowe w rozumieniu ustawodawcy są znakami nadającymi się do „odróżniania w obrocie towarów jednego przedsiębiorstwa od tego samego rodzaju towarów innych przedsiębiorstw" (art. 120 ust. 1 ustawy Prawo własności przemysłowej ${ }^{29}$ [dalej w skrócie: u.p.w.p]). Mogą one przybierać różnorakie postacie: wyrazu, rysunku, ornamentu, kompozycji kolorystycznej, formy plastycznej, melodii lub innego sygnału dźwiękowego, jak również zestawienia tych elementów (art. 120 ust. 2 u.p.w.p.). Najpopularniejszymi i najbardziej typowymi są znaki towarowe słowne. Takie też znaki będą brane pod uwagę w niniejszym opracowaniu, co wynika $\mathrm{z}$ faktu, iż w nazwie domeny internetowej mogą występować znaki towarowe jedynie w postaci słownej.

Zarejestrowane znaki towarowe stają się niejako wizytówkami przedsiębiorstw, świadectwami jakości i niejednokrotnie symbolami prestiżu, będąc używanymi, zgodnie z art. 154 u.p.w.p., w celach marketingowych. Ze względu na coraz powszechniejsze wykorzystywanie Internetu przez

28 Firma jest kwalifikowaną postacią nazwy.

29 Ustawa z dnia 30 czerwca 2001 r. Prawo własności przemysłowej (Dz. U. z 2001 r., Nr 49, poz. 508). 
przedsiębiorstwa, w Sieci pojawiły się witryny tychże przedsiębiorstw, w adresach których zawarto słowne znaki towarowe. Niepodważalne jest prawo przedsiębiorcy do umieszczenia w nazwie domeny zarejestrowanego przez siebie znaku towarowego - wynika to ze wspomnianego art. 154 u.p.w.p. Jednocześnie możliwość posługiwania się (jako zarejestrowanym znakiem towarowym) takim samym oznaczeniem przez więcej niż jedno przedsiębiorstwo (z zastrzeżeniami art. 122 ust. 1 u.p.w.p.) w świetle absolutnego wymogu zachowania niepowtarzalności nazw domen jest częstym powodem konfliktów. Wymóg unikalności nazw domen wynika z przyczyn technicznych; jednej nazwie domeny można przyporządkować tylko jeden adres IP w bazie DNS. Podobnie niemożliwe byłoby funkcjonowanie dwóch telefonów o dokładnie identycznych numerach. Umieszczenie znaku towarowego w nazwie domeny zdecydowanie zwiększa możliwość odszukania witryny danego przedsiębiorstwa, jak również zwiększa szansę na to, iż odwiedzający stronę zapamięta jej adres i (być może) do niego wróci.

Podstawowym problemem, pojawiającym się w trakcie rozważań nad kwestią znaków towarowych jako nazw domen, jest międzynarodowy, nadterytorialny charakter Internetu, skonfrontowany z tradycyjna, terytorialną ochroną znaków towarowych. Jednoznaczne rozstrzygnięcie tej kwestii dodatkowo komplikuje istnienie systemu rejestracji znaków towarowych dla 42 klas towarów i usług, który umożliwia rejestrację identycznych znaków towarowych dla różnych klas towarów lub usług, przy jednoczesnym technicznym ograniczeniu DNS, wymuszającym unikalność każdego adresu domenowego. Jeszcze jedno utrudnienie wynika z faktu, że o ile można rejestrować znaki towarowe w różnych wersjach (słownych, graficznych, przestrzennych itd.), o tyle znak towarowy użyty w nazwie domeny ma zawsze taką samą, słowną postać, co nieuchronnie prowadzi do sytuacji, w której wiele podmiotów uprawnionych do używania konkretnego znaku towarowego będzie próbowało dokonać rejestracji domeny, zawierającej ów znak ${ }^{30}$.

Przykładem takiego układu jest sytuacja, w której znak towarowy glad należy w Wielkiej Brytanii do firmy Procter\&Gamble, natomiast we Francji - do International Machines Corp., w Szwajcarii zaś właścicielem znaku glad jest L'Oreal ${ }^{31}$. Mogą zatem istnieć domeny glad.co.uk (w Wielkiej

30 J. Ożegalska, op. cit., s. 24.

31 M. Kondrat, op. cit., s. 58. 
Brytanii), glad.fr (we Francji) oraz glad.ch (w Szwajcarii). Komu natomiast, wobec takiej sytuacji, będzie przysługiwało prawo do domeny glad.com?

Najwięcej konfliktów o domeny związanych jest z używaniem w ich nazwach znaków towarowych przez podmioty nieuprawnione. Istniejące orzecznictwo sądów zagranicznych rzuca pewne światło na to, kiedy można uznać użycie cudzego znaku towarowego w adresie internetowym za naruszenie. Sformułowane zostały bowiem przesłanki, pozwalające kwalifikować powstające konflikty ${ }^{32}$.

Ostatnią przesłanką naruszenia cudzego prawa do znaku towarowego jest niebezpieczeństwo wprowadzenia w błąd klientów co do pochodzenia towarów lub usług, oferowanych przez podmiot przy pomocy witryny, znajdującej się pod adresem, zawierającym w nazwie właśnie ten cudzy znak towarowy. Niebezpieczeństwo takie zachodzi w przypadkach, gdy adres internetowy strony WWW jest identyczny lub podobny do znaku towarowego, lub gdy za pośrednictwem witryny oferowane są towary lub usługi identyczne bądź podobne do towarów lub usług, dla których znak towarowy został zarejestrowany.

Bardzo często spotykanymi elementami nazw domen są nazwiska. Są one traktowane przez prawo jako dobra osobiste, wymienione pośród innych w art. 23 kodeksu cywilnego ${ }^{33}$ i pozostają pod ochroną prawną zgodnie $\mathrm{z}$ ww. artykułem k.c. W przypadku rejestrowania nazwiska jako nazwy domeny internetowej, należy rozpatrzyć dwie możliwości: rejestracji własnego nazwiska jako nazwy domeny oraz rejestracji w tym charakterze nazwiska cudzego. Szczególnym przypadkiem tej drugiej

32 J. Ożegalska, op. cit., s. 25.

33 Ustawa z dnia 23 kwietnia 1964 r. Kodeks cywilny (Dz. U. z 1964 r., Nr 16, poz. 93; zm.: Dz. U. z 1971 r., Nr 27, poz. 252; z 1976 r., Nr 19, poz. 122; z 1982 r., $\mathrm{Nr} 11$, poz. 81; z 1982 r., Nr 19, poz. 147; z 1982 r., Nr 30, poz. 210; z 1984 r., Nr 45, poz. 242; z 1985 r., Nr 22, poz. 99; z 1989 r., Nr 3, poz. 11; z 1989 r., Nr 33, poz. 175; z 1990 r., Nr 34, poz. 198; z 1990 r., Nr 55, poz. 321; z 1990 r., Nr 79, poz. 464; z 1991 r., Nr 107, poz. 464; z 1991 r., Nr 115, poz. 496; z 1993 r., Nr 17, poz. 78; z 1994 r., Nr 27 , poz. 509; z 1994 r., Nr 84, poz. 386; z 1994 r., Nr 85, poz. 388; z 1995 r., Nr 83, poz. 417; z 1995 r., Nr 141, poz. 692; z 1996 r., Nr 114, poz. 542; z 1996 r., Nr 139, poz. 646; z 1997 r., Nr 43, poz. 272; z 1996 r., Nr 149, poz. 703; z 1997 r., Nr 115, poz. 741; z 1997 r., Nr 117, poz. 751; z 1997 r., Nr 157, poz. 1040; z 1998 r., Nr 117 , poz. 758; z 1998 r., Nr 106, poz. 668; z 1999 r., Nr 52, poz. 532; z 2000 r., Nr 22, poz. 271; z 2000 r., Nr 74, poz. 855 i poz. 857; z 2000 r., Nr 88, poz. 983; z 2000 r., Nr 114, poz. 1191; z 2001 r., Nr 71, poz, 733; z 2001 r., Nr 145, poz, 1638; z 2002 r., $\mathrm{Nr} 130$, poz. 1450). 
możliwości będzie rejestracja w charakterze nazwy domeny nazwiska sławnego lub popularnego (jak Kowalski czy Nowak w Polsce).

Nawet przypadek rejestrowania własnego nazwiska jako nazwy domeny może budzić wątpliwości natury prawnej, gdyż jakkolwiek osobie, której przysługuje prawo do nazwiska, przysługuje również prawo do użycia go w taki sposób (jako nazwy domeny), to można z prawdopodobieństwem graniczącym z pewnością stwierdzić, iż osoba ta nie jest jedynym posiadaczem takiego nazwiska. Zatem, wspomniane wcześniej technologiczne ograniczenia systemu nazw domenowych nie pozwolą na rejestrację wielu identycznie brzmiących nazw domen w sytuacji, gdyby więcej niż jeden właściciel danego nazwiska chciał je zarejestrować jako taką nazwę. Powstaje tutaj konflikt pomiędzy osobami uprawnionymi do nazwiska, w którym wszystkie strony mają jednakową pozycję. Rozwiązanie tego konfliktu powinno, jak sądzę, opierać się na zasadzie pierwszeństwa.

Zdecydowanie bardziej skomplikowanym przypadkiem będzie natomiast sytuacja, w której podmiot próbuje zarejestrować domenę z zamiarem użycia w jej nazwie cudzego nazwiska. Zasadniczo możliwe jest wnioskowanie o rejestrację domeny, zawierającej w nazwie cudze nazwisko, pod warunkiem uzyskania zgody właściciela tego nazwiska - uchyla to bowiem bezprawność działania ${ }^{34}$. Oczywiście, wspomniana zgoda obejmuje jedynie prawo do użycia nazwiska w nazwie domeny, nie zaś zrzeczenie się nazwiska przez osobę, która takiej zgody udziela ${ }^{35}$.

Kolejną sytuacją jest próba rejestracji nazwy domeny zawierającej nazwisko sławne. Powstaje tutaj oczywiście problem definicji pojęcia nazwiska sławnego, gdyż definicja ta - jako taka - nie istnieje. Wywodząc jednakże per analogiam z ochrony znaku towarowego, nazwisko można uznać za sławne, gdy jest znane na większości terytorium kraju, a także jest kojarzone przez mieszkańców tego kraju z konkretną działalnością osoby je noszącej ${ }^{36}$. W zakres ten wchodzą bez wątpienia również nazwiska, które trwale weszły do dziedzictwa kulturowego (jak np. Mickiewicz czy Matejko). Wydaje się oczywiste, iż rejestracja domeny, zawierającej w nazwie sławne nazwisko żyjącej osoby, będzie wymagała udzielenia przez nią zgody. Wymagane również będzie uzyskanie takiej zgody od

34 P. Waglowski, Internet a dobra osobiste człowieka, w: Internet. Fenomen ..., op. cit., s. 319.

35 Por. M. Poźniak-Niedzielska, Użycie cudzego nazwiska jako znaku towarowego, ,Rejent” 1994, nr 7-8, s. 34.

36 R. Skubisz, Prawo znaków towarowych-komentarz, Warszawa 1997, s. 193. 
spadkobierców nieżyjącej osoby o sławnym nazwisku, gdy podmiot wniesie o rejestrację domeny, zawierającej w nazwie owo nazwisko. Dodatkowo, rejestrowanie w nazwie domeny nazwiska, które weszło do dziedzictwa kulturowego, powinno odbywać się przy zachowaniu szczególnych środków ostrożności przez organ rejestrujący. Środki te powinny polegać na konieczności złożenia przez wnioskodawcę możliwie wyczerpujących wyjaśnień, dotyczących celu rejestracji domeny o takiej właśnie nazwie.

W przypadku domeny już zarejestrowanej przez podmiot nieuprawniony, na wniosek osoby posiadającej prawo do nazwiska rejestrator powinien anulować rejestrację i ewentualnie przekazać nazwę domeny do dyspozycji podmiotu uprawnionego do jej używania. Polski organ rejestracyjny - NASK - spełnia jedynie drugi z wymienionych warunków, jednakże tylko w przypadku, gdy zostanie mu doręczony prawomocny wyrok sądu ${ }^{37}$. Jednocześnie NASK nie przyjmuje na siebie obowiązku badania uprawnień wnioskodawcy do zarejestrowania domeny o podawanej przez niego nazwie, zastrzegając przy tym, że za złożenie we wniosku o rejestrację nieprawdziwego oświadczenia o przysługiwaniu prawa do nazwy domeny, odpowiedzialność spoczywa jedynie na składającym wniosek $^{38}$.

Innym rodzajem naruszenia dóbr osobistych przez zarejestrowanie domeny zawierającej cudze nazwisko, jest umieszczenie pod takim adresem treści, które narażają osobę noszącą to nazwisko na utratę dobrego imienia, renomy lub wiarygodności. Do takiego naruszenia może jednak dojść jedynie wtedy, gdy korzystanie z cudzego nazwiska w adresie internetowym rzeczywiście zagraża negatywnymi skutkami faktycznemu dysponentowi dobra, jakim jest nazwisko. Może to mieć miejsce, gdy na stronie WWW prezentowane będą materiały kompromitujące lub ośmieszające osobę, kojarzoną z adresem, pod którym te treści się znajdują. Jak twierdzi J. Ożegalska ${ }^{39}$, odwiedzający taką stronę mogą utracić pozytywne wyobrażenia o danej osobie, oferowanych przez nią usługach i towarach, sądząc, że strona internetowa do tej osoby należy lub jest z nią w jakiś sposób powiązana.

37 Zasady ogólne rejestracji i utrzymywania domen przez NASK, http://www.dns. pl/zasady_p.html.

38 Ibidem.

39 J. Ożegalska, op. cit., s. 27. 
Pomimo tego, że w Polsce nie wypracowano dotąd rozwiązań, regulujących wprost kwestie rejestrowania nazw domen przez podmioty nieuprawnione, istnieją w naszym systemie prawnym przepisy, pozwalające bronić się przed takim procederem, gdyż nie budzi wątpliwości, w świetle funkcjonującego prawa, np. bezprawność cybersquattingu. Można bowiem objąć istniejącą regulacją nowe zjawiska, które wykazują podobny charakter i konsekwencje do zjawisk już znanych. Odpowiednie regulacje zawarto w ustawie o zwalczaniu nieuczciwej konkurencji [dalej: u.z.n.k.]. Według niej, czynem nieuczciwej konkurencji jest związane z działalnością gospodarczą (art. 1 u.z.n.k.) działanie sprzeczne z prawem lub dobrymi obyczajami, jeżeli zagraża lub narusza interes innego przedsiębiorcy lub klienta (art. 3 ust. 1 u.z.n.k.). Ustawa ma zastosowanie w stosunku do podmiotów, które są przedsiębiorcami w rozumieniu art. 2 tejże ustawy, czyli osób fizycznych, osób prawnych oraz jednostek organizacyjnych nie mających osobowości prawnej, które prowadząc, chociażby ubocznie, działalność zarobkową lub zawodową, uczestniczą w działalności gospodarczej.

Podmiot, którego prawa zostały naruszone lub zagrożone przez nieuprawnioną rejestrację nazwy domeny internetowej, może domagać się, zgodnie z polskimi uregulowaniami, trzech podstawowych rodzajów roszczeń:

- roszczenia o zaniechanie działań,

- roszczenia o usunięcie skutków (w szerokim rozumieniu tego terminu, czyli również o odszkodowanie, wydanie bezpodstawnie uzyskanych korzyści oraz wydanie stosownego oświadczenia),

- roszczenia o uiszczenie określonej sumy na dany cel.

W zakres tak ogólnie wyliczonych roszczeń wchodzą żądania ściśle określonych działań. Podstawowym żądaniem jest domaganie się usunięcia domeny, które może być realizowane w ramach roszczenia o zaniechanie. Kategoria zagrożenia interesom, rozróżniana w polskim ustawodawstwie, pozwala na domaganie się usunięcia domeny z systemu od momentu, w którym domena ta została zarejestrowana i jest dostępna w Sieci, natomiast znajdująca się pod tym adresem strona nie jest jeszcze prezentowana i nie zawiera żadnej treści. Konieczne będzie jednakże w takim przypadku wykazanie, iż rejestrujący domenę czynił to z zamiarem użycia jej w sposób niezgodny z prawem. Dopiero przypisanie zamiaru daje możliwość uznania faktu rejestracji za stwarzający zagrożenie dla interesów podmiotu.

Roszczenie odszkodowawcze jako środek ochronny jest w pełni zgodne z polskim systemem prawnym. Można występować o odszkodowanie od 
podmiotu, który bezprawnie zarejestrował domenę (zgodnie z art. 415 i n. k.c.), jednakże wymagane jest tutaj udowodnienie zaistnienia rzeczywistej szkody po stronie występującego $\mathrm{z}$ roszczeniem.

Szkoda ta musi być wynikiem zawinionego postępowania podmiotu bezprawnie dysponującego domeną, zatem konieczne jest wykazanie związku przyczynowo-skutkowego między postępowaniem dysponenta domeny a szkodą. Dodatkowym problemem będzie w takich sytuacjach określenie wysokości szkody, które może być bardzo trudne. Interesujące rozwiązanie tej kwestii zaproponował ustawodawca amerykański, który w Anticybersquatting Consumer Protection Act dopuszcza dwojaki sposób określania wysokości szkody: bądź bezpośrednio przez powoda, bądź też według uznania sądu, w zakresie od 1000 do 100000 dolarów.

Interesująco przedstawiają się pomysły organów Unii Europejskiej w kwestii domen internetowych. Domeny stały się obiektem zainteresowania Komisji Europejskiej, zwłaszcza po opublikowaniu przez amerykański Departament Handlu listy pytań i propozycji, dotyczących rozwoju systemu domenowego, skierowanej do władz Wspólnoty ${ }^{40}$. Uzgodnione przez Komisję stanowisko w tej kwestii dotyczyło intensyfikacji działań na rzecz rozwoju systemu domenowego poprzez zwiększenie konkurencyjności na rynku rejestratorów. Realizacja tych zamysłów polegałaby na przyznaniu nowym podmiotom prawa do rejestrowania domen oraz wprowadzeniu reguł wolnorynkowych, pozwalających na rozwój swobodnej konkurencji pomiędzy profesjonalnymi rejestratorami. Zarządzanie systemem domenowym, według propozycji Komisji Europejskiej, powinno być uregulowane w taki sposób, by opiekę nad nim sprawowało ciało o charakterze międzynarodowym, z odpowiednią reprezentacją państw Wspólnoty. Taka międzynarodowa instytucja decydowałaby również o tworzeniu nowych domen najwyższego poziomu.

W postępowaniu Komisji Europejskiej można dostrzec wyraźne dążenie do zmiany struktury organów zarządzających domenami, którym wielokrotnie zarzucano ,,amerykanocentryzm”. Poza tym, konflikty pomiędzy podmiotami uprawnionymi do używania określonych oznaczeń a rejestrującymi domeny, zawierające w nazwach te oznaczenia, są przedmiotem wnikliwej analizy ze strony ekspertów unijnych ${ }^{41}$. Podkreślają oni, że

40 A Proposal to Improve Technical Management of Internet Names and Addresses, Departament of Commerce US, National and Administration of Internet Domain Names.

${ }_{41}$ Issues involving the registration of Internet domain names, /ECNTIA comment.htm. 
obecnie nie ma możliwości łatwego i jednoznacznego rozwiązywania tego typu sporów, gdyż brakuje odpowiednich regulacji w prawie międzynarodowym, które dotychczas nie objęło w sposób kompleksowy zarówno zagadnień, związanych ze znakami towarowymi, jak i problemu rejestrowania domen internetowych. Wprowadzenie takich uregulowań wydaje się być niezbędne, głównie z powodu lawinowo rosnącej liczby konfliktów o domeny pomiędzy podmiotami, znajdującymi się na różnych terytoriach $\mathrm{i}-\mathrm{w}$ konsekwencji - w zasięgu różnych systemów prawnych, co stwarza kłopot w wyborze sądu właściwego dla rozwiązania sporu.

Osobną częścią stanowiska Komisji Europejskiej była ocena poziomu konkurencji podmiotów, posiadających prawo do działalności w charakterze rejestratora domen. W wielu krajach Europy (w tym w Polsce) funkcjonuje tylko jeden rejestrator, posiadający faktyczny monopol na tego typu działalność. Zwracano uwagę, że możliwa jest sytuacja, w której nie udziela się (bez przekonywującego uzasadnienia) zezwolenia.

Przedstawiona $\mathrm{w}$ tym artykule tematyka znajduje się $\mathrm{w}$ obszarze szczególnego zainteresowania użytkowników Internetu - zwłaszcza instytucji o charakterze komercyjnym. Wiele poruszonych tu problemów pozostaje wciąż dalekimi od rozwiązania i budzącymi znaczne wątpliwości. Zakres ochrony, przyznawany poszczególnym oznaczeniom indywidualizującym, jest zróżnicowany i zasadniczo nigdzie na świecie nie opracowano jednolitego rozwiązania, pozwalającego na skuteczne i jednoznaczne rozwiązywanie konfliktów o domeny internetowe. Starania takie są jednak podejmowane - zarówno na płaszczyźnie wewnątrzpaństwowej, jak i międzynarodowej.

\section{Summary}

A tempestuous expansion of a new means of social communication, the Internet, has come to a stage when the operating principles of the world wide web, initially based on absolute freedom and peculiar ,good manners”, needed order. New types of abuse constantly emerge becoming a challenge for law. Despite the fact that Poland has had a relatively short „Internet history”, the expansion of the Internet has left its traces here as well. The system of registration of the Internet domain names is particularly susceptible to legal offences as it frequently does not prevent illegal use of someone else's property in order to gain direct profits or for the purposes of unfair competition. The scope of protection assigned to individual names is diversified. No uniform solution has been developed anywhere in the world to solve the conflicts concerning the Internet domains in an eff'icient and unanimous manner. 